\section{Taxonomy of Antarctic Flavobacterium species: description of Flavobacterium gillisiae sp. nov., Flavobacterium tegetincola sp. nov. and Flavobacterium xanthum sp. nov., nom. rev. and reclassification of [Flavobacterium] salegens as Salegentibacter salegens gen. nov., comb. nov.}

\author{
Sharee A. McCammon and John P. Bowman
}

School of Agricultural Science, University of Tasmania, GPO Box 252-54, Hobart, Tasmania 7001, Australia

\author{
Author for correspondence: John P. Bowman. Tel: +6136226 2776. Fax: +61362262642. \\ e-mail: john.bowman@utas.edu.au
}

Keywords: Flavobacterium, Antarctica, sea ice, psychrophilic bacteria

\section{INTRODUCTION}

The genus Flavobacterium is widespread in nature and has been isolated from many freshwater and soil habitats. Several Flavobacterium species are pathogens of fish; however this genus appears primarily to play a role in remineralization processes and exhibits strong macromolecular hydrolytic capabilities. Until recently the nomenclatural status of the genus was heterogeneous and confused (Holmes et al., 1984; Bernardet et al., 1996). Recent studies have now resolved many of

The GenBank accession numbers for the 16S rRNA sequences of ACAM strains $81^{\top}, 601^{\top}, 602^{\top}$ and 603 are AF030380, U85889, U85887 and U85888, respectively. these problems resulting in Flavobacterium representing predominantly gliding, pigmented bacteria which have a DNA G + C content of $32-37 \mathrm{~mol} \%$ and menaquinone- 6 as the primary respiratory quinone (Bernardet et al., 1996). Phylogenetic analysis using 16S rRNA sequences and rRNA-DNA hybridization experiments place Flavobacterium in the FlexibacterBacteroides-Flavobacterium phylum (Bauwens \& De Ley, 1981; Woese et al., 1990). Flavobacterium is the type genus of the family Flavobacteriaceae which also encompasses several other genera including Chryseobacterium, Bergeyella, Riemerella, Ornithobacterium, Empedobacter, Weeksella, Capnocytophaga, Myroides, Gelidibacter, Psychroserpens, Polaribacter, Psychroflexus and various generically misclassified Cytophaga 
and Flexibacter species (Bernardet et al., 1996; Bowman et al., 1998).

Several strains related to the genus Flavobacterium have been isolated from a number of Antarctic habitats. Inoue \& Komagata (1976) isolated '[Cytophaga] xantha' from a mud pool near Syowa Station, Antarctica $\left(68^{\circ} \mathrm{S} 39^{\circ} \mathrm{E}\right)$. rRNA-DNA hybridization experiments demonstrated this species was related to Flavobacterium aquatile (Bernardet et al., 1996). Organic Lake, a shallow, meromictic, hypersaline waterbody in the Vestfold Hills ice-free zone of Antarctica $\left(68^{\circ} \mathrm{S} 78^{\circ} \mathrm{E}\right)$ has yielded the species [Flavobacterium] gondwanense and [Flavobacterium] salegens (Dobson et al., 1993). rRNA-DNA hybridization experiments (Bernardet et al., 1996), fatty acids (Skerratt et al., 1991; Bowman et al., 1998) and 16S rRNA sequence analysis (Dobson et al., 1993) indicate that these species do not belong to the genus Flavobacterium but instead represent phylogenetically distinct taxa within the Flavobacteriaceae. [Flavobacterium] gondwanense has been subsequently renamed Psychroflexus gondwanensis (Bowman et al., 1998). Lactose-utilizing isolates from a highly oligotrophic freshwater lake in the Vestfold Hills were described as Flavobacterium hibernum by McCammon et al. (1998). Finally a number of yellow- and orange-pigmented isolates from sea ice and marine salinity lake samples (Franzmann et al., 1990; Bowman et al., 1997a) have been found to be phylogenetically related to the genus Flavobacterium; however 16S rRNA sequence data suggested these strains represent potentially novel species.

In this study phenotypic, fatty acid analysis and genotypic data were utilized to ascertain the relationship of a number of Antarctic sea ice and lake isolates to known Flavobacterium species. From this research it was found the isolates represented two distinct and novel species of Flavobacterium with the following proposed names: Flavobacterium gillisiae sp. nov. and Flavobacterium tegetincola. '[Cytophaga] xantha' was also recognized as a distinct member of the genus Flavobacterium, and is revived as Flavobacterium xanthum. In addition the misclassified species [Flavobacterium] salegens was elevated to genus status to reflect its distinct phylogenetic position and was designated Salegentibacter salegens gen. nov., comb. nov.

\section{METHODS}

Strains and cultivation conditions. Protocols describing the isolation of the Antarctic strains investigated in this study were previously described (Bowman et al., 1997a). Isolates and reference strains investigated in this study are shown in Table 1. All strains utilized in the study were routinely cultivated on R2A medium (Oxoid) at $20^{\circ} \mathrm{C}$.

Phenotypic characterization. Most phenotypic tests have been published previously (Bowman et al., 1997b). Flexirubin pigments were detected by suspending cells in $20 \%$ (w/v) KOH, with a colour change from yellow or orange to brown-red indicative of a positive result (Fautz \&
Reichenbach, 1980). The detection of extracellular glucans by the Congo red absorption test was performed by flooding plates with $0.01 \%(\mathrm{w} / \mathrm{v})$ Congo red (McCurdy, 1969). The procedures of Hildebrand (1971) were followed to test for the degradation of pectin. CMC hydrolysis was tested by overlaying nutrient agar with a thin layer of $0.5 \%(\mathrm{w} / \mathrm{v})$ $\mathrm{CMC}$ in tapwater agar and observing for hydrolysis zones after $21 \mathrm{~d}$ incubation.

DNA base composition. Genomic DNA was extracted and purified from cells using the Marmur \& Doty (1962) procedure. The DNA G + C content was then determined from thermal denaturation profiles using procedures developed by Sly et al. (1986).

DNA-DNA hybridization. The spectrophotometric renaturation rate kinetic procedure adapted by $\mathrm{Huß}$ et al. (1983) was used to determine DNA-DNA reassociation values between genomic DNA of different strains. Genomic DNA was sheared to a mean size of $1 \mathrm{~kb}$ using sonication, dialysed overnight at $4{ }^{\circ} \mathrm{C}$ in $2 \times \mathrm{SSC}$ buffer $(0 \cdot 3 \mathrm{M} \mathrm{NaCl}$, $0.03 \mathrm{M}$ sodium citrate, $\mathrm{pH} 7.0$ ), and adjusted in concentration to approximately $75 \mu \mathrm{g} \mathrm{ml}^{-1}$. Following denaturation of the DNA samples, hybridization was performed at the optimal temperature for renaturation $\left(T_{\mathrm{OR}}\right)$ which was $25^{\circ} \mathrm{C}$ below the DNA melting temperature and was calculated from the following equation: $T_{\mathrm{OR}}{ }^{\circ} \mathrm{C}=48 \cdot 5+(0 \cdot 41 \times \mathrm{mol} \%$ $\mathrm{G}+\mathrm{C}$ ). The decline in absorbance over a $40 \mathrm{~min}$ interval of DNA mixtures and control DNA samples was used to calculate DNA hybridization values from the following equation (Huß et al., 1983):

$$
\begin{aligned}
& \text { Percentage DNA hybridization }= \\
& \qquad(4 \mathrm{AB}-\mathrm{A}-\mathrm{B} / 2 \sqrt{ }(\mathrm{A} \times \mathrm{B})) \times 100 \%
\end{aligned}
$$

$\mathrm{A}$ and $\mathrm{B}$ represent the change in absorbance for two DNA samples being compared and $\mathrm{AB}$ represents the change in absorbance for equimolar mixtures of $\mathrm{A}$ and $\mathrm{B}$. DNA hybridization values equal to or below $25 \%$ are considered to represent background hybridization and are thus not considered to be significant.

Fatty acid analysis. All strains were cultivated on trypticase soya agar (Difco) at $20{ }^{\circ} \mathrm{C}$ for $2 \mathrm{~d}$, harvested and then lyophilized using a vacuum freeze-drier (Dynavac). Wholecell fatty acid profiles were quantitatively determined using gas chromatographic and GC-MS procedures (Nichols et al., 1986). The geometry and position of double bonds in monounsaturated fatty acids was confirmed using dimethyldisulfide derivatization and analysis using GC-MS. The double-bond positions are numbered from the methyl $(\omega)$ end of the fatty acid.

Phylogenetic analysis. The 16S rRNA gene sequences for representatives of the isolates (ACAM $601^{\mathrm{T}}$ and ACAM $603^{\mathrm{T}}$ ) were obtained in an earlier study (Bowman et al., 1997a). The sequence for '[Cytophaga] xantha' ACAM 81 ${ }^{\mathrm{T}}$ was obtained in this study. Conditions and reagents used for PCR amplification and sequencing of 16S rRNA sequences have been previously published (Bowman et al., 1997a). Sequence reactions were prepared with the Prism dRhodamine terminator cycle sequencing ready reaction kit (Applied Biosystems). Electrophoresis and sequence reading were performed on a A377 DNA sequencer (Applied Biosystems). The sequences used in the study were compared to the compilation of $16 \mathrm{~S}$ rRNA genes available in the GenBank nucleotide database. The complete sequences were aligned with hypervariable regions aligned according to secondary structure. Subsequent phylogenetic analyses of 
Table 1. Strain designation and sources of Antarctic strains, Flavobacterium species and related species compared in this study

\begin{tabular}{|c|c|c|}
\hline Species & Strain* & Isolation site \\
\hline \multicolumn{3}{|l|}{ Antarctic } \\
\hline Flavobacterium sp. & ACAM $601^{\mathrm{T}}$ & Coastal sea ice \\
\hline Flavobacterium sp. & ACAM $602^{\mathrm{T}}$ & Cyanobacterial mat \\
\hline Flavobacterium sp. & ACAM 603 & Cyanobacterial mat \\
\hline '[Cytophaga $]$ xantha' & ACAM $81^{\mathrm{T}}=$ NCIMB $2069^{\mathrm{T}}$ & Pool mud \\
\hline Flavobacterium hibernum & ACAM $376^{\mathrm{T}}$ & Freshwater lake \\
\hline \multicolumn{3}{|l|}{ Non-Antarctic } \\
\hline Flavobacterium flevense & ACAM $579^{\mathrm{T}}=\mathrm{NCIMB} 12056^{\mathrm{T}}$ & Freshwater lake \\
\hline Flavobacterium hydatis & NCIMB $2215^{\mathrm{T}}$ & Gills of diseased salmon \\
\hline Flavobacterium saccharophilum & ACAM $581^{\mathrm{T}}=\mathrm{NCIMB} 2072^{\mathrm{T}}$ & River water \\
\hline Flavobacterium psychrophilum & NCIMB $1947^{\mathrm{T}}$ & Kidney of salmon \\
\hline $\begin{array}{c}\text { Flavobacterium sp. ('[Sporocyto- } \\
\text { phaga] cauliformans' type } 2 \text { ) }\end{array}$ & ACAM $580=$ NCIMB 9488 & Lakewater \\
\hline
\end{tabular}

* ACAM, Australian Collection of Antarctic Microorganisms, University of Tasmania, Hobart, Tasmania, Australia; NCIMB, National Collection of Industrial and Marine Bacteria, Aberdeen, UK.

the sequence datasets utilized PHYLIP (version 3.57c) (Felsenstein, 1993). DNADIST was used to determine sequence similarities using the maximum-likelihood algorithm option. Phylogenetic trees were constructed with the neighbourjoining method by using the program NEIGHBOR. Bootstrap analysis was performed using SEQBOOT and CONSENSE using 250 resamplings of the dataset.

\section{RESULTS AND DISCUSSION}

\section{Morphological and phenotypic properties of Antarctic strains}

All of the Antarctic strains investigated, including '[Cytophaga $]$ xantha' ACAM $81^{\mathrm{T}}$, formed yellow or yellow-orange pigments; however the $\mathrm{KOH}$ test results indicated flexirubin pigments were absent. Gliding motility tests were performed on full- and quarterstrength R2A agar media with growth examined after 7 and $16 \mathrm{~h}$ incubation. From microscopic observations only the cyanobacterial mat strains ACAM 602 and ACAM 603 appeared capable of gliding motility. All of the strains were able to grow on seawater agar (marine 2216 agar and R2A agar prepared with $35 \mathrm{~g}$ artificial sea salts $1^{-1}$ ), could grow at $0{ }^{\circ} \mathrm{C}$ but were unable to grow at $30^{\circ} \mathrm{C}$ or higher. The isolates were able to form acid oxidatively from D-glucose in Leifson's oxidation/fermentation medium (Leifson, 1963) and in addition could use D-glucose as a sole carbon and energy source. However, none of strains were able to grow fermentatively or grow by anaerobic respiration using ferric iron, nitrate, nitrite or trimethylamine $N$-oxide as electron acceptors. On this basis the isolates are strictly aerobic. The capacity to degrade macromolecules and some other compounds varied considerably between the isolates as indicated in Table 2. None of the isolates were susceptible to vibriostatic agent $\mathrm{O} / 129$ or were able to adsorb Congo red dye, indicating the absence of glucan-type polysaccharides. Likewise, none of the strains could hydrolyse ONPG, form brown diffusible pigments on tyrosine agar, form precipitates or clearing on eggyolk agar or produce acid from L-arabinose, Lrhamnose, D-xylose, melibiose, raffinose, adonitol, Dsorbitol or inositol. The remaining traits investigated vary between the strains studied and are useful for their differentiation (Table 2). '[Cytophaga] xantha' ACAM $81^{\mathrm{T}}$ was reinvestigated phenotypically and the results were in general accordance with those reported by Inoue \& Komagata (1976). Additional phenotypic tests were performed so that a better comparison could be made with other Flavobacterium species (Table 2).

\section{Fatty acid profiles}

The Antarctic strains possessed similar whole-cell fatty acid profiles (Table 3), with the major constituents

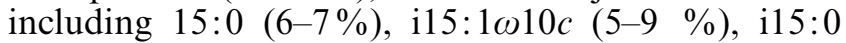
$(5-11 \%)$, a $15: 0(6-15 \%), 15: 1 \omega 6 c(2-21 \%), 16: 1 \omega 7 c$ $(18-23 \%)$ and 3-OH i15:0 (6-13\%) (Table 3). Overall, the profiles were similar to fatty acid profiles determined for other Flavobacterium species (Bernardet et al., 1996) with quantitative differences mostly due to the different lipid extraction and cultivation conditions protocols employed between this and other studies.

\section{Genotypic analysis}

The DNA $\mathrm{G}+\mathrm{C}$ contents of the strains (Table 2) fell within the range typical for sensu stricto Flavobacterium species ( $32-37 \mathrm{~mol} \%$ ). The $\mathrm{mol} \% \mathrm{G}+\mathrm{C}$ of ACAM $81^{\mathrm{T}}$ was $36 \mathrm{~mol} \%$, which is similar to the result from Bernardet et al. (1996). Inoue \& Komagata (1976) originally reported a DNA G $+\mathrm{C}$ content of $39 \mathrm{~mol} \%$ for ACAM $81^{\mathrm{T}}$. DNA-DNA hybridization 
Table 2. Phenotypic characteristics differentiating the Antarctic and other Flavobacterium species

Flavobacterium species: $1, F$. gillisiae; $2, F$. tegetincola; $3, F$.xanthum; $4, F$. flevense; $5, F$. hibernum; 6, F. aquatile; 7, F. branchiophilum; 8, F. columnare; 9, F. psychrophilum; 10, F. hydatis; $11, F$. johnsoniae; $12, F$. pectinovorum; $13, F$. saccharophilum; and 14, F. succinicans. Abbreviations: + , test is postive; $(+)$, test positive, weak or delayed response; - , negative test result; $v$, test results vary between strains of species; $\mathrm{ND}$, data either not available or are unreliable.

\begin{tabular}{|c|c|c|c|c|c|c|c|c|c|c|c|c|c|c|}
\hline \multirow[t]{2}{*}{ Character } & \multicolumn{14}{|c|}{ Flavobacterium species:* } \\
\hline & 1 & 2 & 3 & 4 & 5 & 6 & 7 & 8 & 9 & 10 & 11 & 12 & 13 & 14 \\
\hline \multicolumn{15}{|l|}{ Growth on: } \\
\hline Seawater agar & + & + & + & + & - & - & - & - & - & - & - & - & - & - \\
\hline Nutrient agar & + & + & + & + & + & - & - & - & - & + & + & + & + & + \\
\hline Trypticase soy agar & + & + & + & + & + & $(+)$ & - & - & - & + & + & + & + & + \\
\hline Growth at $25^{\circ} \mathrm{C}$ on agar & $(+)$ & $(+)$ & $(+)$ & + & + & + & + & + & - & + & + & + & + & + \\
\hline Gliding motility & - & + & - & + & + & + & - & + & $(+)$ & + & + & + & + & + \\
\hline Flexirubins & - & - & - & - & + & - & - & + & + & + & + & + & + & - \\
\hline Glucose utilization & + & + & + & + & + & ND & ND & - & - & + & + & + & + & + \\
\hline Acid from carbohydrates & + & + & + & + & + & + & + & - & - & + & + & + & + & + \\
\hline \multicolumn{15}{|l|}{ Degradation of: } \\
\hline Gelatin & - & - & + & - & + & & + & + & + & + & + & + & + & $(+)$ \\
\hline Casein & + & - & + & - & + & + & + & + & + & + & + & + & + & + \\
\hline Starch & + & - & + & ND & + & & + & - & - & + & + & + & + & + \\
\hline $\mathrm{CMC}$ & - & - & - & - & - & - & - & - & - & ND & + & + & + & ND \\
\hline Agar & - & - & - & + & - & - & - & - & - & - & - & - & + & - \\
\hline Pectin & - & - & - & + & - & ND & ND & ND & - & + & + & + & + & ND \\
\hline Chitin & + & - & - & - & - & - & - & - & - & $(+)$ & + & + & - & - \\
\hline Aesculin & + & - & + & + & + & & - & - & - & + & + & + & + & + \\
\hline DNA & - & - & - & - & + & - & - & + & $(+)$ & + & + & + & - & + \\
\hline Tyrosine & - & - & - & - & + & & + & - & $\mathrm{V}$ & + & + & + & + & - \\
\hline Precipitate on egg yolk medium & - & - & - & - & - & + & + & + & + & - & - & - & - & - \\
\hline ONPG hydrolysis & - & - & - & + & + & ND & + & - & - & + & + & + & + & + \\
\hline $\mathrm{H}_{2} \mathrm{~S}$ production & - & - & + & - & - & - & - & + & - & - & - & ND & + & + \\
\hline $\mathrm{NO}_{3} \rightarrow \mathrm{NO}_{2}$ & - & - & + & ND & + & ND & - & ND & - & + & + & + & + & $\mathrm{V}$ \\
\hline $\mathrm{Mol} \% \mathrm{G}+\mathrm{C}($ mean $)$ & 32 & 32 & 36 & 35 & 36 & 33 & 33 & 32 & 35 & 34 & 34 & 35 & 33 & 36 \\
\hline
\end{tabular}

* Data from Bernardet et al. (1996), McCammon et al. (1998) and this study.

analyses indicated strains ACAM 602 and ACAM 603 were closely related, sharing a reassociation level of 87 $( \pm 10) \%$, corresponding to the close phylogenetic affiliation of these strains. ACAM $601^{T}$ was genotypically distinct, sharing reassociation levels at less than $25 \%$ with its closest phylogenetic relatives, ACAM $81^{\mathrm{T}}$ and F. psychrophilum. Likewise, no significant DNA hybridization was found for any of the Antarctic strains with Flavobacterium flevense ACAM $582^{\mathrm{T}}$, Flavobacterium saccharophilum ACAM $580^{\mathrm{T}}$ or Flavobacterium hibernum ACAM $376^{\mathrm{T}}$.

\section{Phylogeny}

Surveys of bacteria from a variety of Antarctic habitats have revealed a rich diversity of novel organisms as well as interesting bacterial associations such as pro- nounced enrichments of psychrophilic bacteria in seaice diatom assemblages and within maritime lakes (Bowman et al., 1997a). From these studies, a number of yellow to orange pigmented strains were found to be related phylogenetically to the genus Flavobacterium. The phylogenetic relationship of all sensu stricto Flavobacterium species and the Antarctic strains are shown in Fig. 1. ACAM $601^{\mathrm{T}}$ was $92 \cdot 9-95 \cdot 2 \%$ similar to the 16S rRNA of other Flavobacterium species. The 16S rRNA sequences of cyanobacterial mat strains ACAM $602^{\mathrm{T}}$ and ACAM 603 were very similar $(99.3 \%$ ) forming a distinct branch within the Flavobacterium clade, sharing a $93.0-94.5 \%$ similarity to other Flavobacterium 16S rRNA sequences. In this study, the 16S rRNA sequence of '[Cytophaga] xantha' ACAM $81^{\mathrm{T}}$ was generated and found to cluster loosely with ACAM $601^{\mathrm{T}}$. Phylogenetically, ACAM $81^{\mathrm{T}}$ was 
Table 3. Whole-cell fatty acid profiles (percentage composition) of Antarctic Flavobacterium species

\begin{tabular}{|c|c|c|c|}
\hline Fatty acid & $\begin{array}{c}F \text {. gillisiae } \\
\text { ACAM 601 }\end{array}$ & $\begin{array}{r}F . \text { tegetincola } \\
\text { ACAM } 602^{\mathrm{T}}\end{array}$ & $\begin{array}{c}\text { '[Cytophaga }] \\
\text { xantha' } \\
\text { ACAM 81' }\end{array}$ \\
\hline i13:0 & - & $0 \cdot 2$ & - \\
\hline a13:0 & - & $0 \cdot 3$ & - \\
\hline $\mathrm{i} 14: 1 \omega 9 c$ & $0 \cdot 2$ & - & - \\
\hline $\mathrm{i} 14: 0$ & $0 \cdot 7$ & $0 \cdot 8$ & $0 \cdot 3$ \\
\hline $14: 0$ & $0 \cdot 4$ & $0 \cdot 5$ & $0 \cdot 4$ \\
\hline $15: 1 \omega 6 c$ & $21 \cdot 5$ & $1 \cdot 8$ & $7 \cdot 9$ \\
\hline $\mathrm{i} 15: 1 \omega 10 c$ & $5 \cdot 1$ & $8 \cdot 9$ & $7 \cdot 3$ \\
\hline a15: $1 \omega 10 c$ & $1 \cdot 3$ & $5 \cdot 7$ & $2 \cdot 2$ \\
\hline $\mathrm{i} 15: 0$ & $5 \cdot 1$ & $8 \cdot 0$ & $10 \cdot 6$ \\
\hline a15:0 & $5 \cdot 8$ & $15 \cdot 4$ & $10 \cdot 5$ \\
\hline $15: 0$ & $7 \cdot 4$ & $6 \cdot 5$ & $6 \cdot 9$ \\
\hline $16: 1 \omega 9 c$ & - & - & - \\
\hline $16: 1 \omega 7 c$ & $21 \cdot 7$ & $18 \cdot 4$ & $23 \cdot 1$ \\
\hline $16: 1 \omega 5 c$ & $0 \cdot 6$ & $0 \cdot 6$ & $0 \cdot 4$ \\
\hline $\mathrm{i} 16: 1 \omega 6 c$ & $3 \cdot 2$ & $3 \cdot 8$ & $0 \cdot 5$ \\
\hline $16: 2^{*}$ & - & $0 \cdot 3$ & - \\
\hline i16:0 & $3 \cdot 5$ & $4 \cdot 8$ & $1 \cdot 3$ \\
\hline $16: 0$ & $2 \cdot 9$ & 1.9 & $2 \cdot 1$ \\
\hline $17: 1 \omega 6 c$ & $0 \cdot 9$ & $2 \cdot 3$ & $0 \cdot 3$ \\
\hline $\mathrm{i} 17: 1 \omega 7 c$ & $4 \cdot 4$ & $3 \cdot 1$ & $4 \cdot 0$ \\
\hline $\mathrm{i} 17: 1 \omega 5 c$ & $1 \cdot 0$ & $3 \cdot 5$ & $2 \cdot 6$ \\
\hline i17:0 & $0 \cdot 2$ & - & $0 \cdot 3$ \\
\hline a $17: 0$ & $1 \cdot 5$ & - & - \\
\hline $18: 0$ & $0 \cdot 6$ & - & - \\
\hline 3-OH i15:0 & $10 \cdot 0$ & $5 \cdot 7$ & $13 \cdot 1$ \\
\hline $3-\mathrm{OH}$ a $15: 0$ & $0 \cdot 2$ & $1 \cdot 0$ & $0 \cdot 8$ \\
\hline 3-OH 15:0 & $0 \cdot 3$ & $0 \cdot 5$ & $1 \cdot 2$ \\
\hline 3-OH i16:0 & $0 \cdot 8$ & $2 \cdot 8$ & $2 \cdot 0$ \\
\hline $3-\mathrm{OH}$ a $16: 0$ & $0 \cdot 4$ & $0 \cdot 1$ & $0 \cdot 2$ \\
\hline 3-OH 16:0 & $0 \cdot 4$ & $1 \cdot 1$ & $1 \cdot 7$ \\
\hline 3-OH i17:0 & $0 \cdot 5$ & $3 \cdot 0$ & $0 \cdot 3$ \\
\hline
\end{tabular}

* Double-bond positions not determined.

distinct from all other Flavobacterium species with the most similar 16S rRNA being that of Flavobacterium psychrophilum (sequence similarity $95.7 \%$ ).

On the basis of polyphasic analysis, the Antarctic strains represent two distinct and novel Flavobacterium species. Each species is from a different habitat and possess different phenotypic traits (Table 2). The Antarctic species differ from 'mainstream' Flavobacterium species in not possessing flexirubin pigments, are tolerant to seawater and most lack gliding motility. However, these traits are not totally conserved within Flavobacterium. Some species, including $F$. aquatile, $F$. branchiopilum, $F$. flevense and $F$. succinicans also lack flexirubin pigments while $F$. branchiophilum is unable to glide. F. flevense is able to grow quite well on seawater agar. This suggests the genus Flavobacterium is phenotypically diverse but other data indicates that it is conserved at the chemo-

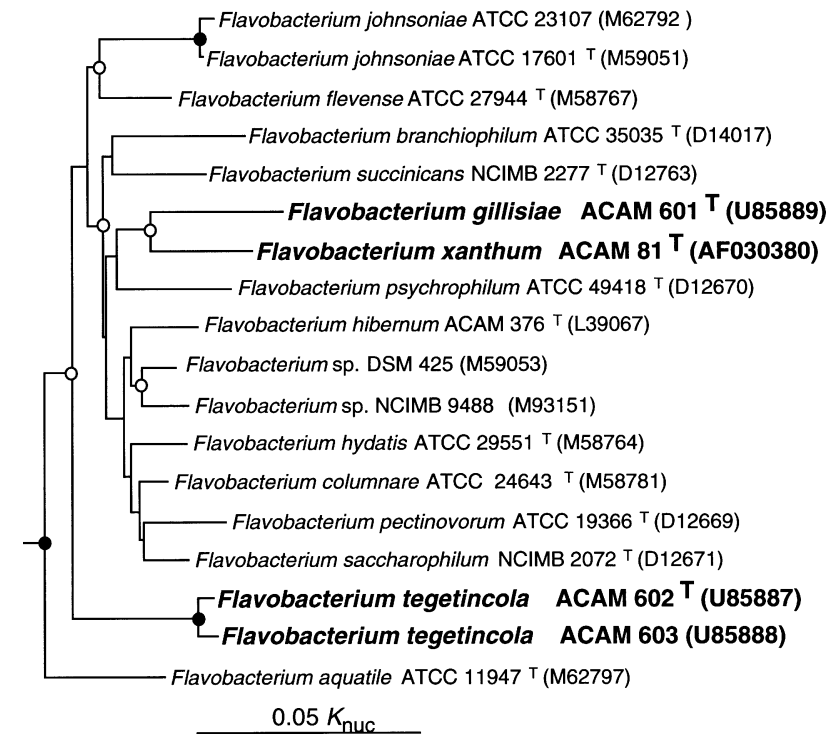

Fig. 1. Phylogenetic relationships of Flavobacterium species based on 16S rRNA sequence comparison. Species in bold type are new species. The branch lengths and branching pattern were generated by maximum-likelihood and neighbour-joining methods. Outgroup sequence used was Myroides odoratus (M58777). The circles at the branch nodes represent bootstrap values, with filled circles indicating bootstrap values of $76-100 \%$, while open circles indicate bootstrap values of $50-75 \%$. The numbers in parentheses are accession numbers for the GenBank nucleotide sequence database.

taxonomic and phylogenetic levels. The degree of phenotypic diversity in Flavobacterium may only be revealed following the isolation and description of new species. A consequence of this diversity is that a degree of reliance on phylogenetic and chemotaxonomic analysis is necessary for the definitive identification of flavobacteria. The following names (and type strains) are proposed as two new Antarctic species: Flavobacterium gillisiae ACAM $601^{\mathrm{T}}$ and Flavobacterium tegetincola ACAM $602^{\mathrm{T}}$. Our results also indicate that '[Cytophaga] xantha' ACAM $81^{\mathrm{T}}$ is a distinct species in the genus Flavobacterium and thus the species is revived as Flavobacterium xanthum comb. nov.

\section{Description of Flavobacterium gillisiae sp. nov.}

Flavobacterium gillisiae (gil.is.i'ae. M.L. gen. gillisiae of Gillis, named after Monique Gillis, a microbiologist who pioneered new techniques for bacterial taxonomy).

Gram-negative rods, $2-5 \mu \mathrm{m}$ in length and $0 \cdot 4-0 \cdot 5 \mu \mathrm{m}$ in width. Non-motile. Cell masses from aerobic cultures are orange. Flexirubin pigments not detected. Colonies have a butyrous consistency, are circular and convex in shape, and possess an entire edge. Sodium nitrate, ammonium chloride, L-glutamate, peptone and Casamino acids serve as nitrogen sources. Vitamins are not required for growth but are stimu- 
latory. Does not require $\mathrm{NaCl}$ for growth however grows well on seawater-containing media and tolerates up to $5 \% \mathrm{NaCl}$. On solid media growth occurs at $0-27^{\circ} \mathrm{C}$, with optimal growth at about $20^{\circ} \mathrm{C}$ while no growth occurs at $30^{\circ} \mathrm{C}$ or above. Strictly aerobic chemoheterotroph. Produces acid from D-glucose, Dmannose, D-galactose, D-fructose, sucrose, trehalose, cellobiose, maltose, D-mannitol and glycerol, but not from L-arabinose, L-rhamnose, D-xylose, lactose, melibiose, raffinose, adonitol, D-sorbitol or inositol. Degrades casein, starch, aesculin, chitin and Tween 80, but not gelatin, agar, alginate, CMC, pectin, DNA, urea, uric acid or xanthine. The arginine dihydrolase test is positive. Lysine decarboxylase, ornithine decarboxylase and tryptophan deaminase activity is absent. Nitrate reduction, indole from L-tryptophan, $\mathrm{H}_{2} \mathrm{~S}$ production, Voges-Proskauer, Simmons' citrate and oxidase tests are negative. Catalase-positive. Can utilize D-glucose as a sole carbon source. DNA G $+\mathrm{C}$ content is $32 \mathrm{~mol} \%$ (determined by the thermal denaturation method). Type strain is ACAM $601^{\mathrm{T}}$, isolated from sea ice from Prydz Bay, Antarctica.

\section{Description of Flavobacterium tegetincola sp. nov.}

Flavobacterium tegetincola (te.get'in.col.a. L. n. teges a mat or rug; L. gen. n. L. incola an inhabitant; M.L. gen. $n$. tegetincola the mat-inhabitant, pertaining to its cyanobacterial mat habitat).

Gram-negative rods, $2-5 \mu \mathrm{m}$ in length and $0.4-0.5 \mu \mathrm{m}$ in width. Motile by gliding. Cell masses from aerobic cultures are yellow. Flexirubin pigments not detected. Colonies have a butyrous consistency, are circular and convex in shape, and possess an entire edge. Peptone and Casamino acids, but not sodium nitrate, ammonium chloride or L-glutamate, serve as nitrogen sources. Vitamins are not required for growth. Nonhalophilic but can grow on seawater-containing media and tolerates up to $5 \% \mathrm{NaCl}$. On solid media growth occurs at $0-27{ }^{\circ} \mathrm{C}$ with optimal growth at about $20^{\circ} \mathrm{C}$ while no growth occurs at $30^{\circ} \mathrm{C}$ or above. Strictly aerobic chemoheterotroph. Produces acid from Dglucose, D-fructose and D-mannitol, but not from L-arabinose, D-galactose, D-fructose, L-rhamnose, D-xylose, sucrose, trehalose, cellobiose, maltose, melibiose, raffinose, adonitol, D-sorbitol, inositol or glycerol. Degrades Tween 80, but not gelatin, casein, aesculin, starch, agar, alginate, chitin carboxymethylcellulose, pectin, DNA, urea, uric acid or xanthine. Arginine dihydrolase, lysine decarboxylase, ornithine decarboxylase and tryptophan deaminase activity are absent. Nitrate reduction, indole from L-tryptophan, $\mathrm{H}_{2} \mathrm{~S}$ production, Voges-Proskauer, oxidase and Simmons' citrate tests are negative. Catalase-positive. Can utilize D-glucose as a sole carbon source. DNA $\mathrm{G}+\mathrm{C}$ content is $34 \mathrm{~mol} \%$ (determined by the thermal denaturation method). Type strain is ACAM $602^{\mathrm{T}}$, isolated from cyanobacterial mat material collected from Ace Lake, a marine salinity meromictic lake located in the Vestfold Hills area of Antarctica.
Description of Flavobacterium xanthum sp. nov., nom. rev. (basonym 'Cytophaga xantha' Inoue and Komagata 1976)

The description of the species is the same as given previously by Reichenbach (1989), with the additional information: flexirubin pigments not detected. Ammonium chloride, L-glutamate, peptone and Casamino acids serve as nitrogen sources. Does not require vitamins for growth. On solid media growth occurs at $0{ }^{\circ} \mathrm{C}$, grows optimally at about $20^{\circ} \mathrm{C}$ while no growth occurs at $30^{\circ} \mathrm{C}$ or above. Produces acid from Dglucose, D-fructose, D-mannose, maltose, cellobiose, sucrose, trehalose and D-mannitol, but not from Larabinose, D-galactose, L-rhamnose, D-xylose, lactose, melibiose, raffinose, adonitol, D-sorbitol, inositol or glycerol. Degrades casein, aesculin and Tween 80, but not agar, alginate, chitin, pectin, DNA, urea, uric acid or xanthine. Arginine dihydrolase, lysine decarboxylase, ornithine decarboxylase and tryptophan deaminase activity are absent. Nitrate reduction and hydrogen sulfide production is positive. Denitrification, indole from L-tryptophan, Simmons' citrate tests and Voges-Proskauer tests are negative. Acid from D-glucose in anaerobic media is not detected. Catalase and oxidase-positive. Can utilize D-glucose as a sole carbon source. DNA G $+\mathrm{C}$ content is $36 \mathrm{~mol} \%$ (determined by the thermal denaturation method). Type strain is ACAM $81^{\mathrm{T}}$, isolated from a mud pool near Syowa Station, Antarctica.

\section{Reclassification of [Flavobacterium] salegens}

[Flavobacterium] salegens $\left(\mathrm{ACAM} 48^{\mathrm{T}}=\mathrm{ATCC}\right.$ $51522^{\mathrm{T}}$ ) remains one of the last validly described Flavobacterium species with a misplaced phylogeny. This species is able to grow from 0 to $30^{\circ} \mathrm{C}$ and from 0 to $20 \% \mathrm{NaCl}$ and has been isolated from various meromictic hypersaline lakes in the Vestfold Hills, East Antarctica (Dobson et al., 1993; James et al., 1994). Studies suggest it is an epiphyte of centric diatoms CUand chlorophytes which proliferate at the ice: water interface and in the surface waters of these lakes (James et al., 1994; J. P. Bowman, unpublished data). Phenotypically $[F$. $]$ salegens is most similar to Psychroflexus gondwanensis (ACAM $44^{\mathrm{T}}=\mathrm{ATCC}$ $51278^{\mathrm{T}}$ ) which also occupies the same habitat. Both species possess a very similar morphology, ecophysiology and are non-motile. By comparison, Psychroflexus torquis (ACAM 623 ) is highly adapted to sympagic (sea-ice) habitats and differs considerably from Psychroflexus gondwanensis in terms of morphology and ecophysiology (Bowman et al., 1988), but they are very similar in terms of chemotaxonomy and $16 \mathrm{~S}$ rRNA sequence (Fig. 2). Fatty acid analysis indicates $[F$.] salegens is quite distinct from most other members of the Flavobacteriaceae including Psychroflexus species. The fatty acid pattern of $[F$. salegens in qualitative terms is most similar to that of Gelidibacter algens (Bowman et al., 1998). The profiles of the two species differ by the presence of a $15: 1 \omega 10 c$, 


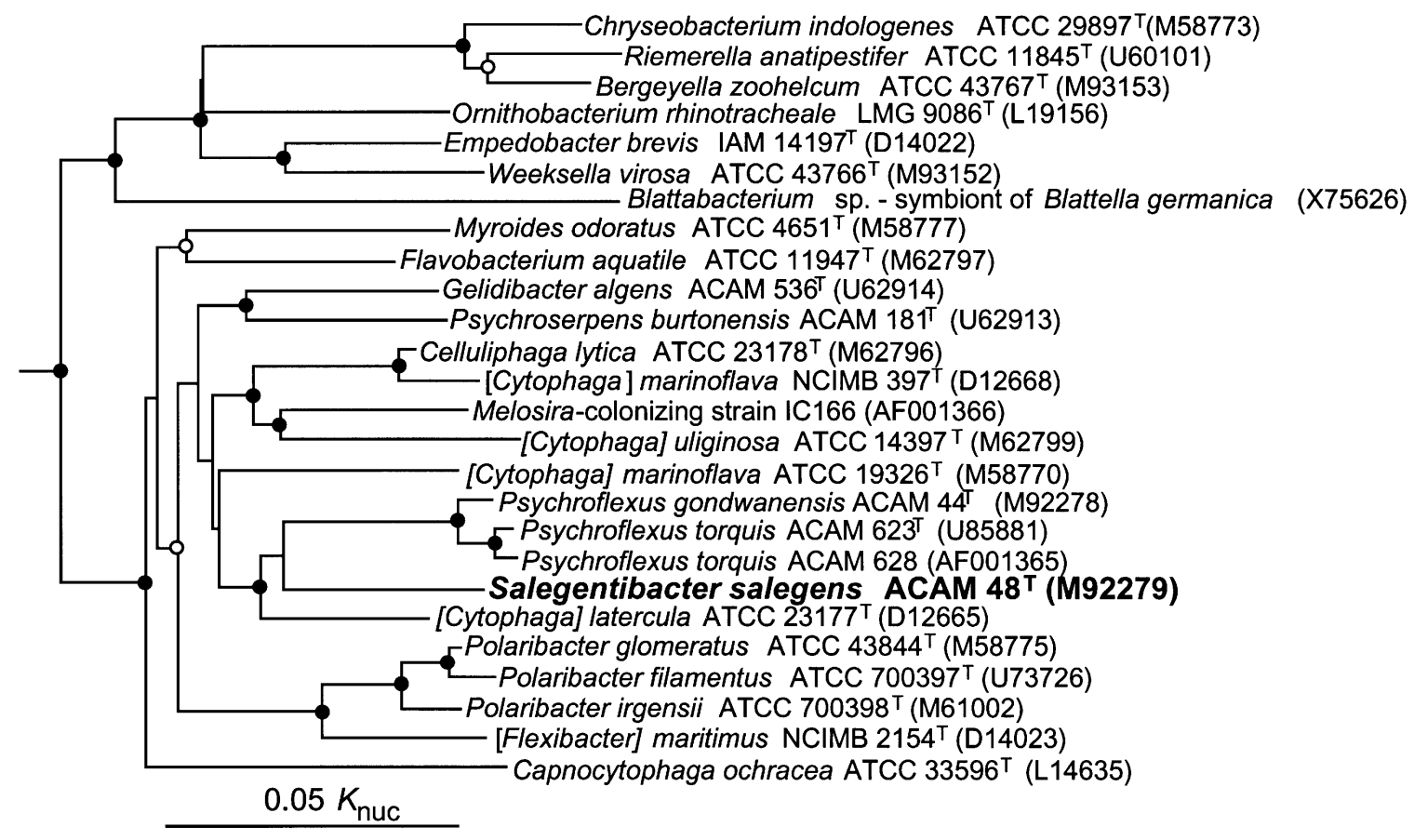

Fig. 2. Phylogenetic relationships of Salegentibacter salegens ([Flavobacterium] salegens) to other members of the family Flavobacteriaceae on the basis of 16S rRNA sequence comparison The branch lengths and branching pattern were generated by maximum-likelihood and neighbour-joining methods. Outgroup sequence used was Bacteroides fragilis (X83935). The circles at the branch nodes represent bootstrap values, with filled circles indicating bootstrap values of 76-100\%, while open circles indicate bootstrap values of 50-75\%. The numbers in parentheses are accession numbers for the GenBank nucleotide sequence database.

Table 4. Phenotypic characteristics that differentiate the genus Salegentibacter from other halophilic members of the Flavobacteriaceae

Abbreviations: - negative; +, positive; $(+)$, weakly positive; $\mathrm{v}$, trait varies between species of the genus; $\mathrm{v}$, trait varies between strains of the genus; O, orange; Y, yellow; R, red; SH, slightly halophilic; $\mathrm{MH}$, moderately halophilic; NH, non-halophilic.

\begin{tabular}{|c|c|c|c|c|c|c|c|c|}
\hline Character & $\begin{array}{l}\text { Salegenti- } \\
\text { bacter }\end{array}$ & $\begin{array}{l}\text { Psychro- } \\
\text { flexus }\end{array}$ & $\begin{array}{c}\text { [Cytophaga] } \\
\text { latercula }\end{array}$ & $\begin{array}{l}\text { Psychro- } \\
\text { serpens }\end{array}$ & $\begin{array}{l}\text { Gelidi- } \\
\text { bacter }\end{array}$ & $\begin{array}{l}\text { Polari- } \\
\text { bacter }\end{array}$ & $\begin{array}{c}\text { [Flexibacter] } \\
\text { maritimus } \\
\text { group* }\end{array}$ & $\begin{array}{c}\text { Celluliphaga } \\
\text { group } \dagger\end{array}$ \\
\hline Gliding motility & - & $\mathrm{V}$ & - & - & + & - & + & + \\
\hline Pigments & $\mathrm{Y}$ & $\mathrm{O}$ & $\mathrm{O}-\mathrm{R}$ & $\mathrm{Y}$ & $\mathrm{Y}$ & $\mathrm{O}$ & $\mathrm{Y}$ & $\mathrm{O}-\mathrm{Y}$ \\
\hline Growth at $25^{\circ} \mathrm{C}$ & + & $\mathrm{V}$ & + & - & $\mathrm{v}$ & - & + & + \\
\hline $\begin{array}{l}\text { Tolerates }>10 \% \\
\mathrm{NaCl}\end{array}$ & + & $\mathrm{v}$ & - & - & - & - & - & - \\
\hline $\begin{array}{l}\text { Requires yeast } \\
\text { extract }\end{array}$ & - & $\mathrm{v}$ & - & + & - & + & + & - \\
\hline Starch hydrolysis & + & + & - & - & + & $\mathrm{v}$ & - & + \\
\hline Agar hydrolysis & - & - & + & - & - & - & - & $\mathrm{V}$ \\
\hline ONPG test & + & - & + & $\mathrm{v}$ & - & $\mathrm{v}$ & - & $\mathrm{v}$ \\
\hline Nitrate reduction & + & - & - & - & - & - & + & $\mathrm{V}$ \\
\hline $\begin{array}{l}\mathrm{Mol} \% \mathrm{G}+\mathrm{C} \\
\left(T_{\mathrm{m}}\right)\end{array}$ & $37-38$ & $32-36$ & 32 & $27-29$ & $36-38$ & $31-34$ & $29-32$ & $32-42$ \\
\hline
\end{tabular}

* Includes [Flexibacter] maritimus and [Flexibacter] ovolyticus.

$\dagger$ Includes Celluliphaga lytica, [Cytophaga] marinoflava and [Cytophaga] uliginosa. 
$15: 1 \omega 11 c$ and $16: 1 \omega 5 c$ in the fatty acid profile of Gelidibacter algens. These fatty acid components are absent in $[F$.] salegens (Skerratt et al., 1991). 16S rRNA sequence analyses also indicates $[F$.] salegens has a distinct position within the family Flavobacteriaceae separate from the genus Flavobacterium and various halophilic genera (Fig. 2). From these results the differentiation of superficially similar taxa such as $[F$. $]$ salegens and Psychroflexus gondwanensis is quite dependent on chemotaxonomic and phylogenetic analysis. However, a combination of phenotypic, chemotaxonomic and phylogenetic traits indicate $[F$. salegens forms a taxon within the family Flavobacteriaceae distinct at the genus level. Thus it is proposed that $[F$.] salegens becomes Salegentibacter salegens gen. nov., comb. nov. in recognition of its distinct phylogenetic position. Table 4 provides tests useful in differentiating Salegentibacter from other halophilic members of the Flavobacteriaceae.

\section{Description of Salegentibacter gen. nov.}

Salegentibacter (Sal.e.gent'i.bact.er. L. n. salis salt; L. part. adj. egentis needy; Gr. n. bakterion rod; L. n. Salegentibacter salt-needy rod; referring to the high level of salt requirement).

Cells are rod-shaped and occur as single cells, pairs and occasionally chains. Non-motile. Do not form spores or other resting stages. Does not form gas vesicles, helical or coiled cells. Colonies are pigmented yellow, however flexirubin-type pigments are not formed. Possesses a strictly aerobic, chemo-organotrophic metabolism. Can utilize inorganic nitrogen sources including ammonia and nitrate. Does not require growth factors. Catalase- and oxidase-positive. Moderately halophilic and highly halotolerant (grows at $0-20 \% \mathrm{NaCl}$, optimal growth at about $5 \% \mathrm{NaCl}$ ). Psychrotolerant, growing between $0-30{ }^{\circ} \mathrm{C}$. Major whole-cell fatty acids are i1 $5: 0$, a $15: 0$, i16:0, i17: $1 \omega 7 c$

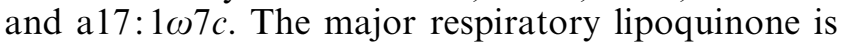
menaquinone- 6 . The $\mathrm{G}+\mathrm{C}$ content of the DNA is $37-38 \mathrm{~mol} \%$ (thermal denaturation method). Member of the family Flavobacteriaceae, Cytophagales division. Only known habitats are the surface waters of hypersaline Antarctic lakes. The type species is Salegentibacter salegens.

\section{Description of Salegentibacter salegens (Flavobacterium salegens Dobson et al. 1993) comb. nov.}

The species description is the same as that for the genus description and as previously described by Dobson et al. (1993). Type strain is ACAM $48^{\mathrm{T}}$ (= ATCC $51522^{\mathrm{T}}$ $=$ DSM 5424 ${ }^{\mathrm{T}}$ ).

\section{ACKNOWLEDGEMENTS}

The research was supported by grants from the Australian Research Council and the Antarctic Advisory Committee (project no. 1012). We are grateful to Jenny Skerratt and
Janelle Brown for fatty acid analyses. We would like to thank Jeremy Carson (Tasmanian Aquaculture \& Fisheries Institute) for strains NCIMB 2215 and NCIMB 1947.

\section{REFERENCES}

Bauwens, M. \& De Ley, J. (1981). Improvements in the taxonomy of Flavobacterium by DNA:rRNA hybridizations. In The Flavobacterium-Cytophaga Group (GPF Monograph Series no. 5), pp. 27-31. Edited by H. Reichenbach \& O. Weeks. Weinheim: Verlag Chemie.

Bernardet, J.-F., Segers, P., Vancanneyt, M., Berthe, F., Kersters, K. \& Vandamme, P. (1996). Cutting a gordian knot: emended classification and description of the genus Flavobacterium, emended description of the family Flavobacteriaceae, and proposal of Flavobacterium hydatis nom. nov. (basonym, Cytophaga aquatilis Strohl and Tait 1978). Int J Syst Bacteriol 46, 128-148.

Bowman, J. P., McCammon, S. A., Brown, M. V., Nichols, D. S. \& McMeekin, T. A. (1997a). Diversity and association of psychrophilic bacteria in Antarctic sea ice. Appl Environ Microbiol 63, 3068-3078.

Bowman, J. P., Skerratt, J. H., Rea, S. M., Nichols, D. S., Nichols, P. D. \& McMeekin, T. A. (1997b). Novel species of Shewanella isolated from Antarctic sea ice with the ability to produce eicosapentaenoic acid $(20: 5 \omega 3)$ and grow anaerobically by dissimilatory $\mathrm{Fe}(\mathrm{III})$ reduction. Int $J$ Syst Bacteriol 47, 1040-1047.

Bowman, J. P., McCammon, S. , Lewis, T., Skerratt, J. H., Brown, J. L., Nichols, D. S. \& McMeekin, T. A. (1998). Psychroflexus torquis gen. nov., sp. nov., a psychrophilic species from Antarctic sea ice, and reclassification of Flavobacterium gondwanense (Dobson et al. 1993) as Psychroflexus gondwanense gen. nov., comb. nov. Microbiology 144, 1601-1609.

Dobson, S. J., Colwell, R. R., Franzmann, P. D. \& McMeekin, T. A. (1993). Direct sequencing of the PCR-amplified 16S rRNA gene of Flavobacterium gondwanense sp. nov. and Flavobacterium salegens sp. nov. new species from a hypersaline Antarctic lake. Int J Syst Bacteriol 43, 77-83.

Fautz, E. \& Reichenbach, H. (1980). A simple test for flexirubintype pigments. FEMS Microbiol Lett 8, 87-91.

Felsenstein, J. (1993). PHYLIP (phylogeny inference package), version 3.57c. University of Washington, Seattle, USA.

Franzmann, P. D., Deprez, P. P., McGuire, A. J., McMeekin, T. A. \& Burton, H. R. (1990). The heterotrophic bacterial microbiota of Burton Lake, Antarctica. Polar Biol 10, 261-264.

Hildebrand, D. C. (1971). Pectate and pectin gels for differentiation of Pseudomonas sp. and other bacterial pathogens. Phytopathology 61, 1430-1436.

Holmes, B., Owen, R. J. \& McMeekin, T. A. (1984). Genus Flavobacterium Bergey, Harrison, Breed, Hammer and Huntoon 1923, 97 ${ }^{\mathrm{AL}}$. Bergey's Manual of Systematic Bacteriology, pp. 353-361. Edited by N. R. Krieg \& J. G. Holt. Baltimore: Williams \& Wilkins.

Huß, V. A. R., Festl, H. \& Schleifer, K. H. (1983). Studies on the spectrophotometric determination of DNA hybridisation from renaturation rates. Syst Appl Microbiol 4, 184-192.

Inoue, K. \& Komagata, K. (1976). Taxonomic study on obligately psychrophilic bacteria isolated from Antarctica. J Gen Appl Microbiol 22, 165-176.

James, S. R., Burton, H. R., McMeekin, T. A. \& Mancuso, C. A. (1994). Seasonal abundance of Halomonas meridiana, Halo- 
monas subglaciescola, Flavobacterium gondwanense, and Flavobacterium salegens. Antarct Sci 6, 325-332.

Leifson, E. (1963). Determination of carbohydrate metabolism of marine bacteria. J Bacteriol 85, 1183-1184.

McCammon, S. A., Innes, B. H., Bowman, J. P., Franzmann, P. D., Dobson, S. J., Holloway, P. E., Skerratt, J. H., Nichols, P. D. \& Rankin, L. M. (1998). Flavobacterium hibernum sp. nov., a lactose-utilizing bacterium from a freshwater Antarctic lake. Int J Syst Bacteriol 48, 1405-1412.

McCurdy, H. D., Jr (1969). Study on the taxonomy of the Myxobacterales. I. Record of Canadian isolates and survey of methods. Can J Microbiol 15, 1453-1461.

Marmur, J. \& Doty, P. (1962). Determination of the base composition of deoxyribonucleic acid from its thermal denaturation temperature. $J$ Mol Biol 5, 109-118.

Nichols, P. D., Guckert, J. B. \& White, D. C. (1986). Determination of monounsaturated fatty acid double-bond position and geometry for microbial monocultures and complex consortia by capillary GC-MS of their dimethyldisulphide adducts. $J$ Microbiol Methods 5, 49-55.

Reichenbach, H. (1989). Family I. Cytophagaceae Stanier 1940, 630, ${ }^{\mathrm{AL}}$ emend. In Bergey's Manual of Systematic Bacteriology, pp. 2013-2050. Edited by J. T. Staley, M. P. Bryant, N. Pfennig \& J. G. Holt. Baltimore: Williams \& Wilkins.

Skerratt, J. H., Nichols, P. D., Mancuso, C. A., James, S. R., Dobson, S. J., McMeekin, T. A. \& Burton, H. R. (1991). The phospholipid ester-linked fatty acid composition of members of the family Halomonadaceae and genus Flavobacterium: a chemotaxonomic guide. Syst Appl Microbiol 14, 8-13.

Sly, L. I., Blackall, L. L., Kraat, P. C., Tian-Shen, T. \& Sangkhobol, V. (1986). The use of second derivative plots for the determination of $\mathrm{mol} \%$ guanine plus cytosine of DNA by the thermal denaturation method. J Microbiol Methods 5, 139-156.

Woese, C. R., Yang, D., Mandelco, L. \& Stetter, K. O. (1990). The Flexibacter-Flavobacter connection. Syst Appl Microbiol 13, 161-165. 